\title{
Introduction to the Research Handbook on Feminist Jurisprudence
}

Robin West

Contemporary feminist legal theory is a body of scholarship produced over the last half of the twentieth century and the first quarter of this one that proffers explanations of law's complicity in the ongoing subordination of women and sexual minorities, while also pursuing the possibilities within law for achieving lasting gender and sex equality. Its purpose is thus both descriptive and critical on the one hand, and normative and aspirational on the other. It attempts, descriptively, to map the contours of the ongoing legal supports for gender- and sex-based subordination in existing law and to explain the persistence of those supports in an era characterized by a liberal consensus on very basic norms of nondiscrimination and formal equality. It is, thus, a critical theory of law. At the same time, however, feminist legal theory is also embedded in - and very actively participates in - the ideals, aspirations and commitments of contemporary legalism, and feminist legal theory's goals are accordingly normative as well as critical. Feminist legal theorists both directly and indirectly contribute to the construction of various fields of law - civil rights law, constitutional law, criminal law, tort law, contract law, family law, international law and private law, and those contributions are to varying degrees aimed at ending just that subordination. That degree of engagement itself rests on the bedrock assumption that those efforts can at least sometimes bear fruit. Thus, feminist legal theory taken in its entirety has shown, if not consistently expressed, a view of law as not only a mechanism for the subordination of over half the human community but also a potential vehicle for equalizing and improving the quality of life for women and all gender and sexual minorities. The working assumption is that law is both complicit in gender and sexual subordination and that legal reform is both possible and essential to gender and sexuality justice. As a consequence, broadly construed, feminist legal theory of the last half century has contributed to our understanding of law's complicity in injustice and its realized and potential contribution to justice and has laid the foundation for our continued study of both.

The critical and the normative sides of feminist legal theory bear the mark of the influence of a number of jurisprudential movements that came to prominence during approximately the same period, including, most notably, liberal legalism, critical legal studies, neo-Marxism, postmodernism and critical race theory. The substantial crossfertilization between feminist legal scholarship and general jurisprudence has given rise to various theoretical branches of and within feminist legal theory, while feminism itself continues to serve as the trunk. Liberal feminist legal theory, to take one example that will be discussed in some detail below, has embraced long-standing liberal values as well as the broad liberal descriptions of social life and human nature on which those values rest. Thus, liberal feminism has largely embraced liberalism's commitment to individualism, according to which all of us are defined primarily by our individual 


\section{Research handbook on feminist jurisprudence}

attributes and ambitions rather than by any socially mandated role or set of presumed characteristics, and the value of autonomy, by which is meant the irreducible importance of self-determination and the pursuit of one's own understanding of the good life without societal or state-based censorial control. Of equal importance to feminism is modern liberalism's commitment to the descriptive claim that all human beings universally share important attributes, including both a capacity for moral reasoning and a desire to contribute to and be included in the political and economic life of the community. Those descriptive claims regarding human nature and its universality undergird liberalism's commitment both to formal equality and expansive rights and liberties that protect individual conscience as well as political participation. Liberal feminism has insisted that these truths of our nature are equally true of women as of men and that the values and commitments based on them must therefore be extended to include women. Liberal feminist legal theory has worked to embed these commitments in law.

To take a second example, radical feminist legal theory, also explored in some detail below, has embraced methods of understanding the nature of exploitation, subordination and alienation that were first explored by Marx and Marxists in relation to labor. Radical feminists have applied these methods and insights - developed in the context of labor - to the exploration of the nature of sexual exploitation suffered by women. In Catharine MacKinnon's now classic exposition, '[s]exuality is to feminism what work is to Marxism: that which is most one's own, yet most taken away.' ${ }^{1}$ This fusion of a feminist political sensibility with neo-Marxist method and insight has enriched feminism's understanding of the centrality of sexual exploitation and alienation to the subordination of women while also enriching Marxism's understanding of the scope of subordination itself. Subordination exists, we can understand radical feminists as insisting, along the axis of sexuality no less than along the axis of labor. A similar claim can be made for each of feminism's theoretical subfields: critical race feminism has enriched both critical race theory and feminism, and postmodern feminism has done likewise for feminism and postmodernism both.

Contemporary feminist legal theory, however, has also been influenced by feminist advocacy, that is, the legal and political advocacy at the heart of the various women's movements of the last century and across the globe. The theoretical advances in feminist (and, indirectly, non-feminist) legal theory thus reflect not only their crossfertilization with jurisprudential movements but also their origins in women's movements during that time. Those prominently include the movements for equal and civil rights in employment and education, ${ }^{2}$ the worldwide campaigns for a woman's right to choose whether to conceive and whether to continue pregnancies to term, ${ }^{3}$ the $1970 \mathrm{~s}$ and 1980s struggles for the right to pursue employment and education free of sexual

1 Catharine A. MacKinnon, Feminism, Marxism, Method, and the State: An Agenda for Theory, 7 Signs 515, 516-17 (1982).

2 See chapters by Sylvia A. Law, In defense of liberal feminism; Katharine K. Baker, Sex equality, gender injury, Title IX and women's education; Kimberly A. Yuracko, Sexual harassment law: an evolution in theory, scope and impact, in this volume.

3 See chapters by Lisa C. Ikemoto, Reproductive rights and justice: a multiple feminist theories account; Noya Rimalt, Against Roe exceptionalism: degendering abortion, in this volume. 
harassment in workplaces and schools ${ }^{4}$ and the right to enjoy physical sovereignty over one's own body free of the dangers posed by rape, sexual assault and sexual battery (or at least secure in the knowledge that the state is committed to protecting against those risks). ${ }^{5}$ All of these political and legal movements have influenced the development of feminist legal theory, sometimes quite directly, sometimes less so. For example, the legal campaign in the United States to secure for women a constitutional right to birth control and abortion has not only extended to women various Fourteenth Amendmentbased rights to privacy, liberty and equality but has also informed feminism's understanding of traditionally liberal commitments of self-determination, selfsovereignty and bodily integrity. ${ }^{6}$ If these commitments to individualism and autonomy are to have meaning for women, then women themselves must have decisional power over their own reproductive lives. And, of course, if liberalism is to make good on its ecumenical promises, it must have meaning for women - thus the conclusion that liberalism itself requires reproductive autonomy. Likewise, the broad legal campaign of the 1970 s and 1980 s to secure rights to be free of sexual harassment in the workplace has deepened our understanding of the role of work in women's and men's lives and the importance of sexual sovereignty and agency in all spheres of life, including but not limited to the workplace. ${ }^{7}$ The exploitation of workers' vulnerabilities, this movement has taught us, does not extend solely to the capture of their surplus labor value by employers; it extends as well to the capture of their sexuality by co-workers, supervisors and customers. Identification of sexual harassment at work as a wrong, then, deepens our understanding of the nature of exploitation generally, not only of women's subordination. A third example is the now sophisticated but still developing understanding in international law and in some domestic legal systems of the contours of a state's duty to protect its citizens and of correlative rights of citizens to that protection, which has been furthered by feminist scholarship on the failure of criminal law and of states to protect women from domestic and sexual violence. ${ }^{8}$ That scholarship has itself been rooted in feminist advocacy, including the attempts by feminist and human rights lawyers to secure recognition in international law of rape as a war crime, ${ }^{9}$ the attempt to secure the abolition of marital rape exemptions and to understand those exemptions as violations of the obligation of states to protect citizens against violence ${ }^{10}$ and the development of legal critiques of so-called honor- and passion-based defenses to violent criminal acts against women that rely on traditional

4 Catharine A. MacKinnon, The Sexual Harassment of Working Women (1976). See also Yuracko, supra note 2.

5 See chapters by Victoria Nourse, Violence against women and liberal sexism; Deborah Tuerkheimer, Sexual agency and the unfinished work of rape law reform, in this volume.

6 See Law, supra note 2.

7 See Tuerkheimer, supra note 5.

8 See chapters by Irem Çağlar and Berna Akçali Gür, The state's due diligence obligation and Adrien K. Wing, International law and feminism, in this volume.

9 See Catharine A. MacKinnon, Butterfly Politics 140-61 (2017).

10 See chapter by Ngaire Naffine, 'Some gentle violence': marital rape immunity as contradiction in criminal law, in this volume. 


\section{Research handbook on feminist jurisprudence}

understandings of women's roles as excusing conditions for often lethal crimes. ${ }^{11}$ All of these advocacy- and practice-based campaigns have informed feminist legal scholarship and its various theoretical branches.

Finally, as noted above, feminist legal theory is a normative field of scholarship as well as being descriptive and critical. It has over time influenced the path of the law and the substance of our politics. Contemporary family law, constitutional law, criminal law and civil rights law have all been changed, and in some cases fundamentally transformed, by contributions from feminist perspectives and advocates, themselves influenced by feminist legal theory. Each of these fields of law as well as others must countenance the equality of women, their equal rights to liberal self-determination and self-regard and their entitlement to an equal regard for their aspirations for liberty, accomplishments and aspirations. Doing so is not as straightforward as changing pronouns to include women in law's domain. Women's lives have been different from men's in the spheres of intimacy, work and public engagement, and their expectations and needs for law, as well as their hopes for it, are therefore different. If women's equality is the premise of women's citizenship and of women's equal protection by and access to law, then the content of that law, and not only the reach of its protection, must change.

And change it has, as the essays in this volume attest. To take some now obvious examples: Criminal law made some decades back for a battered spouse syndrome defense, in part to compensate for the lack of regard it had historically accorded intimate violence - the kind of violence more often sustained by women - and therefore its lack of appreciation of the different dynamics that characterize violence in the intimate sphere as distinguished from violence between strangers in the public sphere. Tort law has begun to countenance the possibility of permitting recovery for negligently and intentionally inflicted emotional harms, in part because women are no longer legally marginalized. The emotional harms women disproportionately sustain have moved toward the center and away from the margins of that body of law. ${ }^{12}$ Family law had to virtually reinvent itself to rectify the ways in which women's domestic labor was historically exploited or ignored and to acknowledge the need to create opportunities for women's greater participation in the public sphere and men's greater participation in the familial sphere without sacrificing the needs of children for parental involvement. ${ }^{13}$ Civil rights law has expanded its purview well beyond the antidiscrimination norm, both to embrace the harms women sustain by virtue of their subordination that cannot be captured by the norm of formal equality - not only harms inflicted through sexual harassment at work but also harms inflicted through facially neutral

11 See Victoria Nourse, Passion's Progress: Modern Law Reform and the Provocation Defense, 106 Yale L.J. 1331 (1997); Self-Defense and Subjectivity, 68 U. Chi. L. Rev. 1235 (2001); Hearts and Minds: Understanding the New Culpability, 6 BuFf. CRIM. L. REv. 361 (2002); Lama Abu-Odeh, Honor Killings and the Construction of Gender in Arab Societies, 58 AM. J. Comp. L. 911 (2010). See also chapters by Tuerkheimer, supra note 5; Naffine, supra note 10; Nivedita Menon, Sexual violence and the law in India, in this volume.

12 See chapter by Martha Chamallas, Feminist legal theory and tort law, in this volume.

13 See chapter by Susan Frelich Appleton, How feminism remade American family law (and how it did not), in this volume. See generally Martha Albertson Fineman, The Neutered Mother, The Sexual Family, and Other Twentieth Century Tragedies (1995). 
workplace norms that adversely impact women's advancement - and to include visions and aspirations of civic inclusion in workplaces and public spheres that go beyond the mandate of being treated the same as men have been. ${ }^{14}$

The remainder of this introduction will explore this interplay between feminist legal theory and other contemporary movements in legal theory on the one hand, and between feminism and positive law on the other. The first two sections look at liberal and radical feminist legal theory respectively, with a primary focus on the profound differences but also on the substantial shared ground between them. I will look in particular at the influences of extra-feminist theoretical movements, most notably liberalism and critical legal studies, on the development of both subfields, as well as at the influence of political and legal advocacy. The third section then introduces the major remaining subfields within feminist legal theory, including relational feminism (sometimes called cultural or difference feminism), critical race feminism (sometimes called intersectional feminism), socialist feminism, postmodern legal feminism, and sex-radical feminism (sometimes subsumed within queer theory). For each, attention is paid to the influence of non-feminist theory and law on the development of each substrand and to the influence of the particular feminist legal theory on the ultimate path of our law. The conclusion makes tentative predictions regarding the trajectory of theoretical legal feminism.

\section{LIBERAL LEGAL FEMINISM}

The liberal legal feminism developed over the last 50 years, as its name suggests, yokes distinctive liberal political commitments to feminist aspirations and then draws out the implications for law. This has not been a seamless union or an easy marriage. By the three-quarter mark of the last century, liberal political theory had come to be defined by its embrace of three major values, each of which in turn rested on a broad description of human nature, the state and the relationship of both to civil society. First, twentiethand twenty-first-century liberalism adheres to an expansive commitment to the value of individual liberty or, more broadly, of individualism, and to an account of individual human nature that undergirds it. Individuals and their fulfilled individual choices are the primary source of value, and therefore individuals must be as free as possible given maximal liberty and authority - to make choices through their own volition and in accordance with their own conception of the good and of the good life. Respecting individual choices made by individuals in open markets is deemed to be the best way to create value, whether value is in turn defined as subjective utility, objective well-being or personal autonomy. Second, liberalism eventually came to embrace - and indeed be identified with - a commitment to the formal equality of persons under the purview of a liberal state - what some call liberalism's 'anti-caste principle.' ${ }^{15}$ This value as well -

14 See Law, supra note 2; Yuracko, supra note 2. See generally Ellen D. Katz, Justice Ginsburg's Umbrella, in A NATION OF WidENING OPPORTUNITIES: THE CIVIL RIGHTS ACT AT FIFTY 264 (Samuel Bagenstos and Ellen Katz eds., 2014); Julie C. Suk, Disparate Impact Abroad, in id. at 283.

15 Cass Sunstein, The Anticaste Principle, 92 Mich. L. Rev. 2410 (1994). 


\section{Research handbook on feminist jurisprudence}

the value of formal equality - rests on a set of descriptive and aspirational claims, the most central of which is that every individual should be regarded as similarly situated - that is, basically the same - with respect to those attributes that matter for legitimate state purposes. Thus, every person is naturally bestowed with a capacity for reason, an autonomous will and an entitlement to be treated with dignity and respect. That universalism, however, is thin. Beyond those universals, we are all individuals and our nature is radically individualistic, with no shared group characteristics; our identity is determined by our own choices and individualized attributes, not by any group-defined status, set of characteristics or role. ${ }^{16}$ Third, modern liberalism has adhered to the conviction that the private sphere, largely construed - including our intimate lives, our familial lives and our commercial lives - is a realm of interactions between free and autonomously self-determined individuals, while the public sphere - the sphere of regulation, politics and government - albeit necessary, poses a potential danger to the freedom of the individual and of the private sphere. The public arm of the state, therefore, is a potential source of oppression, while the private realms of intimacy, family and commerce are places of freedom and nurturance. The private sphere must be protected against possible encroachments from the public sphere.

The jurisprudential view that is now commonly called liberal legalism consists of the attempt by legal and constitutional philosophers to outline the basic contours of legal systems that embrace these liberal commitments. The impact of liberal legalism is felt in virtually all areas of law, but in some fields - US constitutional law, civil rights law, contract law and family law - more heavily, and concretely, than others; and liberal legalists have created a sizeable body of literature mapping that domain. In US constitutional law, according to liberal legal constitutional scholars, liberal commitments to individual autonomy and the importance of individualistic conceptions of value and of the good life are reflected in strong protections for individual rights generally, and more specifically in First Amendment protections of individual (and corporate) deliberation, decision-making and expression, particularly in the realms of political and religious life. ${ }^{17}$ The liberal valorization of the private sphere and wariness toward the state, politics and the public realm are all reflected in a very general identification of constitutional rights with negative rights that counsel a restrained rather than activist state, a range of individual rights to speech and belief, substantive due process rights against state encroachment on the private sphere and a conception of privacy that is so extensive as to protect commercial and sexual life as well as the spheres of religion, community and family. ${ }^{18}$ In contract law, the impact of liberalism has been felt in the diminution over the last five decades of nineteenth- to midtwentieth-century constraints on contractual freedom, including the demise of various 'policing' doctrines internal to contract law, such as the unenforceability of unconscionable contracts and equitable constraints on the consideration doctrine, as well as expansion of the realm of contract to areas once excluded, such as prenuptial agreements and surrogacy agreements, and in the gradual expansion, over the same

16 See Ronald Dworkin, On Liberalism, in A MATTER OF PRINCIPLE 188 (1985).

17 See, e.g., Bruce A. Ackerman, Social Justice in the Liberal State (1980).

18 See chapter by Mary Anne Franks, Beyond 'Free Speech for the White Man': feminism and the First Amendment, in this volume. 
time period, of contractual limits on various non-contractual legal obligations and rights, such as rights to sue and rights to nondiscrimination. ${ }^{19}$ All of these expand the realm of individual self-determination through the expansion of legally binding contractual obligations and the diminution of legal obligations not defined by contract. Finally, in the United States and elsewhere the liberal commitment to formal equality has been concretized in a broadly embraced body of civil rights law which commits states and major employers to an antidiscrimination principle forbidding discrimination and segregation against members of groups on the basis of immutable characteristics, including race, ethnicity, religious affiliation, gender and, increasingly, sexual orientation and gender expression as well. ${ }^{20}$

These three core liberal commitments - to individualism, to formal equality and to the creation and protection of a private sphere into which the state may not intrude have provided extraordinarily fertile ground for the expansion of women's liberty and rights, both in theory and in practice, and collectively they have come to be strongly identified with liberal feminist legal theory as well. First, liberal individualism - the broad claim that we are each of us determined by individual rather than group traits and that our lives must be to the greatest degree possible driven by our individually chosen rather than assigned paths - undercuts entirely the justification for separate spheres ideology, the cult of domesticity, the exclusion of women from various male professions, trades and jobs, and the general exclusion of women from public life. If women are not, contrary to centuries-long teachings, peculiarly a group for familial tasks and peculiarly incapacitated for masculine pursuits, then there is no justification for their exclusion from the public world and restriction to the intimate. Nor should men be incapacitated from the familial or be presumed better suited for the public. Rather, all women, individually, as well as all men, should be the authors of their own fates through their own choices that reflect their own individual aspirations, capacities and will. Not all women are cut out to be firefighters or legislators, or medical doctors or lawyers, but then neither are all men; and therefore questions regarding whether, and which, women should have a claim to those professions and callings must be a function of individual capacities and decisions. Likewise, not all women are cut out to be mothers, nor are all men cut out for fatherhood; to the greatest degree possible, these modes of living should be a matter of individual inclination and choice. Not all women are best suited for secretarial work, or waitressing, or grade school teaching, or nursing or maternal labor, although some may be, as is true of some men. These ways of life themselves are not pernicious - indeed it is contrary to the individualist premises of both feminism and liberalism to view them as such - but the channeling of one gender or the other into them runs roughshod over liberal and feminist commitments to individual freedom. Whether to partake in any particular way of life must be the

19 See chapter by Hila Keren, Feminism and contract law, in this volume.

20 See chapter by Julie A. Nice, The gendered jurisprudence of the Fourteenth Amendment, in this volume. See generally Paul Brest, The Supreme Court 1975 Term. Foreword: In Defense of the Antidiscrimination Principle, 90 Harv. L. Rev. 1-55 (1976); 3 Bruce ACKerman, We the People: The Civil Rights Revolution (2014). 


\section{Research handbook on feminist jurisprudence}

decision of the individual, made without the constraints of socially imposed expectations defined by gender or sex. ${ }^{21}$

The liberal commitment to formal equality, or the anti-caste principle, has also become a clear underpinning of liberal feminism and of liberal feminist legal theory. Women, according to the liberal commitment to formal equality, can be neither treated nor viewed as unequal to male counterparts or as essentially different from them in ways that would in turn justify unequal and worse (or better) treatment. Women as a group, then, cannot be excluded from forms of political life and expression, such as the vote or the jury box, or from economic or social fora of association, such as private clubs, or from public spaces, such as the public square or legislative assembly. Any state action which segregates women or treats them differently because it presumes otherwise is unjustified and today will almost assuredly be found unconstitutional in US law. ${ }^{22}$ Thus, social security laws that favor widows over widowers (and therefore favor deceased male spouses over deceased female spouses) on stereotypical grounds regarding need and breadwinning capacities, or military benefits that do likewise, have been ruled unconstitutional, basically on anti-caste grounds. ${ }^{23}$ Single-sex schools maintained so as to perpetuate stereotypical conceptions of masculinity and femininity have met the same fate. ${ }^{24}$ Women and men should be treated as individuals. But more concretely, women may not be treated differently as a group based on false and stereotypical assumptions regarding their nature.

Third, the liberal commitment to the value of an untrammeled private sphere has likewise been absorbed by liberal feminism and liberal feminist legal theory, although in a particular context rather than across the board, and with significant reservations rather than unequivocally. Reproductive rights, both to birth control and abortion, are justified largely (not entirely) by a commitment to the exercise of choice within a private domain, untrammeled by moralistic conceptions of right and wrong that often dictate the criminalization of those processes, products and decisions. ${ }^{25}$ Similarly, gay and lesbian sexuality, marriage and parenthood are often threatened by undue legislative intrusion into these private realms. Liberal feminism has for the most part followed

21 For early discussions and formulations of liberal feminism and its commitment to equality, see Wendy W. Williams, The Equality Crisis, Some Reflections on Culture, Courts, and Feminism, 14 Women's RTS L. REP. 151 (1992); Ruth Bader Ginsburg, Some Thoughts on Autonomy and Equality in Relation to Roe v. Wade, 63 N.C. L. REv. 375 (1985). For a recent application, see Naomi Mezey and Cornelia T. L. Pillard, Against the New Maternalism, 18 MiCH. J. GENDER \& L. 229 (2012).

22 For discussion of the early sex discrimination cases under the Fourteenth Amendment, see Nice, supra note 20.

23 Frontiero v. Richardson, 411 U.S. 677 (1973) (invalidating military benefits given differentially on the basis of sex); Weinberger v. Wiesenfeld, 420 U.S. 636 (1975) (invalidating social security scheme allowing widows but not widowers to receive survivors' benefits based on the deceased spouse's earnings).

24 Mississippi University for Women v. Hogan, 458 U.S. 718, 725-26 (1982) (invalidating single-sex admissions policy of the Mississippi University for Women); United States v. Virginia, 518 U.S. 515 (1996) (invalidating single-sex admissions policy of the Virginia Military Institute).

25 See Ikemoto, supra note 3. See generally EILEEN L. MCDonOugh, BREAKING THE Abortion Deadlock: From Choice to Consent (1996); Jed Rubenfeld, The Right of Privacy, 102 HARV. L. REV. 737 (1989). 
liberalism in its inclination to defend these spheres of sexuality against legislative intrusion.

The resulting nondiscrimination rights, the critical stance toward all gender distinctions grounded in positive law and the respect for women's choices regarding child-bearing, reproduction and sexuality that now characterize liberal legal regimes have contributed to women's equality and liberty in countless ways. It may be fair to conclude that the embrace of these liberal commitments by feminist political advocates, and eventually by feminist legal theorists, has proven to be more than justified. That absorption - the embrace of liberalism and its principles by so many feminist legal theorists - has not, however, been without costs, nor has it been without criticism from feminists as well as other political actors. The three liberal commitments listed above to individual autonomy, to a broad opposition to caste-based or stereotypical treatment of groups and to the valorization of the private sphere - have had costs for women, some easily seen and some more subtle. I will mention three, all of which are discussed in greater detail in the chapters that follow.

First, the liberal and liberal feminist insistence on the value of autonomy and the consequent reliance on women's choices and stated preferences as a guide to their well-being and liberty frees women from the constraints of domesticity, of role, of gender stereotypes and the caged pedestal. At the same time, however, it feeds a neoliberal inclination to overly valorize or, more simply, to unduly rely upon individual consent as the harbinger of value, that is, to infer value, or goodness, from the behavioral fact of individual consent. This reliance can be deeply misguided. Consent is not always a consistent or even rough indicator of a transaction that will enhance the felt life or life prospects of the person who renders it. A laborer who unquestionably consents to work may be consenting to a bad deal which has little to commend it other than its being better than any proffered alternative, but it may nevertheless be a bad deal. A consumer who consents to a sales contract with disclaimers and mandatory arbitration clauses may likewise have unquestionably consented, but it does not follow that the agreement is a good one. A decent legal system, or reform, should aim to provide better alternatives, not simply free the power of the laborer or consumer to proffer consent free of paternalistic state interference with the contract on the table. Giving women the power to consent to participate in the sex trade, pornography or to poorly paid jobs with no paid leave for maternity care, or to sex with boyfriends or johns or pimps or supervisors or teachers they do not welcome and may abhor may free them from worse alternatives, but it should nevertheless not be heralded as having provided utility-maximizing trades or bargains, liberating and improving the lives of all participants. Consent to bad deals can go a long way toward legitimating those deals, or at least acquiescing in their necessity. Celebrating all consensual trades, bargains or transactions as good - because they are the free result of unfettered consensual trades runs the risk of insulating those transactions even from critique, much less from regulation. That legitimation, that acquiescence and that celebration - along with the deregulation that often accompanies it - may be unjustified when prompted by the consent of any subjugated group. It might be particularly and poignantly so for women, for whom a training in self-sacrifice and domestic altruism - and therefore a training for the rendering of apparent consent under coercive conditions - is such a central part of the mechanisms of social control that perpetuate their subordination. The high value 
placed on individualism and autonomy by liberal feminists has accordingly been subjected to considerable criticism by radical feminists and others peculiarly attuned to the ways in which subordination is often achieved, not necessarily at gunpoint but rather through the more subtle extraction of the consent of the weak. ${ }^{26}$

Second, while the high value placed on the private sphere by liberalism and liberal feminism has insulated some women's private decisions regarding contraception and abortion from state interference, as well as the lives and choices of sexual minorities from the preening eye of moralistic state legislators, protection of familial privacy has also carried real risks. Women, children and sexual minorities have also struggled with the failure of states to protect them against the harms, injuries and violence visited upon them in those private and intimate spheres. While liberalism has therefore been a helpful corrective to the harmful moralism of state legislators, it has failed to provide any sort of theoretical corrective to the state's failures to protect women, children and sexual minorities against the sexual violence they suffer in the privacy of their homes. The danger posed by liberalism, and particularly by liberal feminism, quite simply is that the privacy that liberalism bestows will not be worth the loss of the protection against violence that insulation entails. Women need their individual choices regarding their own reproductive and sexual lives and bodies respected, but they also need their bodies protected against the violence that the veil of privacy can sometimes insulate. ${ }^{27}$

Lastly, the complex commitment to formal equality and the claim of a universal, cross-gender human nature on which it rests carry promise but also peril for women. The now widely held view that women and men are similarly endowed with the capacities for reason, moral action, political deliberation and the ability to perform in careers and trades is a vital breakthrough for liberalism, feminism and justice; women's exclusion from spheres of employment and the public world of politics has largely been justified, when justification was felt to be needed, on spurious claims of women's incapacities for those pursuits. The peril from the seemingly self-evident claim of broad similarity across sexual and gender lines arises from the spheres of life and experience in which women and men are not so similar, or in which women's paths diverge, for whatever reason. Women's reproductive lives are undeniably different from men's: women experience both wanted and unwanted pregnancies, menstruation, lactation and childbirth, which impact their bodies and often their health, while men do not. Women also have sexual lives that are on average different from men's in at least two important respects: they are more vulnerable to sexual assault and rape, and they are as a result more vulnerable to nonconsensual impregnation that can result from those assaults. The differences do not end, however, with these biological markers. Women and girls arguably, or at least much of the time, experience a different acculturation, which leaves them on average more conciliatory, passive and acquiescent, as well as arguably

26 See chapter by Chao-ju Chen, Catharine A. MacKinnon and equality theory, in this volume; CATHARINE A. MACKInNON, Rape: On Coercion and Consent, in TOWARD A FEMINIST THEORY OF THE STATE 171-83 (1989) [hereinafter FEMINIST THEORY OF THE StATE]; CATHARINE A. MacKinnon, Francis Biddle's Sister: Pornography, Civil Rights, and Speech, in FEMINISM UnMODIFIED 163-97 (1987) [hereinafter FEMINISM UnMODIFIED]. See also Robin West, Sex, Law and Consent, in The Ethics of Consent: Theory And Practice (Franklin G. Miller and Alan Wertheimer eds., 2009).

27 See Chen, supra note 26; MACKInNOn, Feminism UnMOdIFIED, supra note 26, at 93-102. 
more inclined toward a moral imperative structured around duties of caregiving rather than one of principle and abstract consistency. And of course women are less powerful, wealthy, privileged and educated than men are worldwide. A liberalism and a liberal feminism predicated on claims of sameness can have perhaps unintended consequences that are not always optimal for women. It can render the profoundly differentiating experiences of pregnancy and childbirth invisible because they are not part of the shared experiential pool of the cross-gender universal human prototype; it can fail to countenance altogether intimate sexual violence because it is so disproportionately visited upon women, girls and sexual minorities; it can fail to attend to the coercive social structures that produce consent from women and girls to much of their subordination; and it can reward only those women who are already most like men, shattering on their behalf glass ceilings but rendering all the more invisible the struggles of those nowhere near the top, whose conditions leave them so unlike men as to benefit almost not at all from a legal regime of nondiscrimination. Although the universalist ideals, claims and ambitions of liberalism tend it toward a generous assimilation of previously excluded outsiders and a suspicion of stereotyping claims that justify intolerance, even those clearly laudable aims can have the effect of entrenching a status quo, albeit one that has broadened to accept those who were once irrationally excluded. It might not, however, have the critical capacity to question the terms of inclusion.

\section{RADICAL FEMINIST LEGAL THEORY}

Radical feminist legal theory owes its origins to a distinctive insight, felt dimly through first- and second-wave feminist movements in the nineteenth and twentieth centuries but stated most forcefully over the last half-century by Catharine MacKinnon, that women's sexuality, including the entire sphere of women's sexual acts, sexual choices, sexual desires and sexual being, is a site of women's exploitation and subordination. To use her phrasing, women's sexuality 'is that which is most her own but most taken from her.' 28 As such, women's sexuality and its ownership by others objectively defines what it is to be a woman. A woman simply is a being from whom sex can be taken for the benefit, pleasure, use and profit of others - much as, for Marxists, a laborer is a human being from whom labor can be taken. Women's sexuality is objectified rendered a thing to be owned or had - and then alienated from them in acts of rape and sexual assault most forcefully, but also through marriage, prostitution, trafficking, pornography and harassment. It is taken without their consent by force or coercion, and it is taken with their apparent or real consent in exchange for promises of safety, economic maintenance, affection or money. But either way, it is taken. It is taken with or without their cooperation, their acquiescence or their complicity and regardless of their own desires, pleasures, initiative, lack of pleasure, desire or initiative. Women are primed as girls to submit to the forced alienation of their sex and sexuality - to accept that alienation willingly - through a training in passivity conveyed in their upbringing, culture, religious traditions and education, all of which contain powerful lessons in the

28 MacKinnon, supra note 1 , at 516-17. 


\section{Research handbook on feminist jurisprudence}

virtue or necessity of feminine submissiveness. The alienation of sexuality that is at the root of women's subordination results in unwanted and often lethal maternity, lowered participation in labor markets, lesser educational opportunities, overt discrimination, shrunken political participation and markedly lessened credibility. A woman's identity as defined by the alienation of her sexuality marks her as a vessel for sex, rather than as an equal citizen. It also renders her, in the minds of herself and others, politically unequal, incapable of reason, unequally and unduly emotional and sentimental, unequally altruistic and caring in the intimate sphere, and to be valued as such, so long as contained within walls.

The law's complicity in the alienation and expropriation of women's sexuality is both direct and indirect, both overt and covert, both transparent and opaque. On the one hand, laws in both liberal and illiberal societies directly empower men to exploit and appropriate women's sexuality through long-standing legal regimes the world over that permit, or until very recently have permitted, the chastisement and rape of wives by husbands, that permit or ignore the pimping and purchase of sexual labor from women at starvation wages, that facilitate or turn a blind eye to the sale of young girls into marriage or prostitution and that steadfastly refuse to investigate, prosecute or convict women's rapists or sexual assailants. Even in liberal societies in which rape, sexual assault and marital rape are all clearly criminal, the law encourages or condones the alienation of women's sexuality in a host of more subtle ways, including protecting the propagation of pornography - texts which encourage and sexualize the sexual assault of women and girls under the guise of free speech - and giving wide latitude to sexual harassment in workplaces and schools, sometimes under a similar rationale. ${ }^{29}$ Radical feminism, with its singular focus on sexual violence and the subordination of women through sexual transactions and assaults committed in the private sphere, opens a window not only on non-liberal or traditional state facilitation of the subordination of women but also on liberalism's facilitation of the same subordination. It thus helps us to understand the otherwise peculiar staying power of mechanisms of women's subordination even within liberal societies, which on their face should seemingly be averse to it. Simply put, somehow the subordination of women persists not only in traditional or illiberal societies but also in liberal legal cultures that have embraced both antidiscrimination norms and the criminalization of sexual assault and battery. Radical feminism provides a theoretical account of how that has happened and of how law might be used more effectively to end it.

More specifically, radical feminist legal theory provides the groundwork for a radical feminist critique of both liberalism and liberal legalism, including feminist liberal legalist achievements and aspirations. Refer back to the three core liberal commitments embraced by liberal feminism listed above - the importance of protecting a private sphere from the state, a universalist understanding of human nature and the necessity of restraining state action so as to protect individual autonomy. Each of these is problematic if we assume that there is some truth in the radical feminist claim that female sexuality is one of, and perhaps the, linchpin of women's subordination. First, the liberal commitments to the privacy and insularity of the private worlds of intimacy and family life have the consequence, which radical feminism distinctively highlights,

29 See Chen, supra note 26. 
of further insulating the private sphere and the violence, subordination and alienation that occurs within that sphere. ${ }^{30}$ Protecting reproductive rights by conceiving of them as within the sphere of privacy rights guarded against state interference has the effect of further insulating or legitimating the hierarchical relations within that sphere. ${ }^{31}$

Second, the universalist premises of liberalism that ground both antidiscrimination norms and the liberal commitment to formal equality are a compromised victory if women's subordination has the appropriation of sexuality at its core. Rigorous gender neutrality from the state will not address, because it will not see, the appropriation of female sexuality. The state may, for example, treat women and men the same with respect to marital rape exemptions - exempting the rape of husbands as well as wives from the reach of the state's criminal arm - and the effect will be that the marital rape of women will go unaddressed. Likewise, the state could evenhandedly decide to decriminalize rape altogether, and so long as it did so in a gender-neutral way, it would not necessarily fail to respect the demands of gender neutrality or formal equality. ${ }^{32}$ More broadly, subordination - whatever its cause - will not be addressed if the antidiscrimination norm is premised upon the assumption that women and men are basically the same for all purposes that should matter to the state. Women and men are not the same to whatever degree women's interests are subordinated to men's, and that degree is considerable: women are less educated, poorer, less skilled, more vulnerable to sexual violence and less politically active. Thus, both the cause of subordination - the appropriation of sexuality - and its consequences - women's lesser lives - are unaddressed and to a considerable degree valorized or legitimated by insistence on formal equality.

Third, both the quintessentially liberal deference to individual choice and the equally quintessential liberal suspicion of states and state action will backfire if the linchpin of women's subordination is the appropriation of women's sexuality. Women's choices will be determined by their subordinate condition, and an undue valorization of choice, particularly those choices that are born of sexual alienation and false consciousness, will thus simply freeze the conditions for those choices in place. Likewise, an across-the-board suspicion of states and state action will deprive feminism of the use of the state to police against, deter or compensate sexual injuries. The subordination of women is accomplished in private spaces, by private actors, through criminal means. The state can and should be expected to protect women against just those criminal invasions. A state unduly minimized, indeed vilified, by those who seek to protect the privacy within which women are subordinated, whether done by liberals in the name of individual liberty or by traditionalists in the name of patriarchy, does women very little good.

Radical feminism also provides the basis for a critique of traditional Marxism: Marxism overstates the degree to which subordination takes place exclusively along an axis of labor subordination and alienation and misses entirely the ways in which it occurs along an axis of sexuality. Thus, radical feminism highlights not only the ways

30 See id. See generally MACKInNon, Feminist TheORY of the State, supra note 26, at 184-94.

31 See id. at 101-02.

32 See Naffine, supra note 10. 
in which liberalism fails to see the private subordination of women through sexuality but also the ways in which Marxism, even if fully attuned to private sphere subordination, nevertheless fails to see that subordination when it is facilitated through sexual rather than labor subordination. ${ }^{33}$ It methodologically follows Marxism up to a point: it highlights the effects of private subordination on women's consciousness; it has within it a critique of liberal rights, particularly rights to privacy and autonomy, that echo Marxist critiques of rights of contract and property; and it contemplates a public role for political action that is not overly concerned with the interests of individuals in keeping the state distant. Its application of the methodological tools of traditional Marxism - the understanding of the mechanisms of alienation, the capacity to see that alienation in consensual transactions, the appreciation of the power of private groups and actors, including cultural and intellectual actors, in creating conditions for private sphere subordination, and the complicity of states in private sphere subordination through the protection of those realms of insularity - to the realm of sexuality, however, is utterly novel. It is as novel, in fact, as the application by liberal feminists of the tools of analysis and change rooted in liberalism to the distinctive circumstances of gender.

Although they have different premises, goals and methods, nevertheless the degree of common ground among radical feminism, liberalism and liberal feminism, on the one hand, and radical feminism and Marxism, on the other, should not be understated. Radical feminism is by no means foreign to either liberal feminism or to liberalism per se, and in both cases, their shared point of contact lies in their appreciation of law and of its capacity for improving lives, as well as its capacity for facilitating subordination. Radical feminism distinctively targets sexual expropriation and alienation of female sexuality as the point, and origin, of women's subordination. That expropriation and alienation, however, are accomplished through the commission of acts of violence by private actors on other private actors or, put differently, through the commission of crimes that can and should be, and sometimes are, targeted by the state. The protection of individuals from the criminal violence occasioned upon them by other private actors is key to philosophically liberal understandings of the raison d'être of the state. Radical feminism seeks the protection of the state to expand that sphere of protection to include sexual crimes and to target the coercion of sex that is at their core. The insistence that the state use its muscle to protect women against violent crime is hardly antithetical to the purposes and ends of the liberal state. It is, rather, very much at its core, and for that reason, radical feminism, whatever its commitment to radicalism methodologically, is also profoundly liberal in its view of the basic role of the state in the prevention of private violence. Liberal and radical feminists share a commitment to the guarded use of state power - liberals to protect women against discrimination, and radicals to protect women against subordination, particularly subordination brought on through sexual violence.

What radical feminism shares with Marxism is also vivid. Radical feminists, like Marx and Marxists, are attuned to the mechanisms of power as wielded by private entities or individuals (capitalists, for Marxists, and men, for radical feminists), the ways in which that power is internalized by the subordinate class and eventually comes to define it. Both are likewise attuned to the ways in which law, in liberal regimes,

33 See MacKinnon, Feminist Theory of the State, supra note 26, at 23-36. 
facilitates that exercise of sovereignty in the private sphere. Rights of property and contract and eventually even rights of nondiscrimination and speech facilitate the appropriation of the surplus value of labor and thus the subordination of workers' interests to those of their employers. In a parallel way, rights of privacy, of speech and of autonomy facilitate the appropriation of the surplus value of women's sexuality and thus the subordination of women's interests to those of men. Patriarchy, like capitalism, uses the rhetorical powers of law, rights and sovereignty, alongside the rhetorical powers of culture, to acculturate both men and women - the former to instill a sense of entitlement, and the latter to instill a sense of inevitability.

Thus, radical feminism employs the analytic tools of Marxism to understand the role of law in women's subordination but at the same time shares with liberals a commitment to the use of the state to resist violence against women that has the effect of alienating them from their sexuality. It is, in other words, radical in its critical orientation but also deeply liberal in its stance toward the law. For example, it fully embraces the mandate of equal protection and aims to extend that mandate to include the equal protection of women against sexual violence. As a consequence, while radical feminism shares with critical legal studies an indebtedness to Marxism, unlike critical legal studies and Marxism, it is, no less than liberal feminism, fully committed to the project of legalism, that is of using law in a way that respects its norms and aspirations, including most centrally its norm and ideal of equal protection. Lastly, while radical feminist legal theory shares with liberal legal feminism both a commitment to the well-being of women and to the legal project of improving women's lives through law and law reform, it views constitutional law and its regime of rights that both broaden liberty and shrink the state with suspicion and looks instead to quite different areas of law - sexual harassment law and criminal law - as the means by which the appropriation of women's sexuality - and hence the cause of women's subordination might be meaningfully addressed, and rectified.

\section{FEMINIST LEGAL THEORIES: DIVISION AND MULTIPLICITY}

Radical and liberal feminist legal theories emerged as discrete and competing approaches to women's inequality in the 1980s. They sharply contrast on several key axes. Liberal and radical feminist theorists held and still hold opposing views regarding the reliability of women's choices, particularly their sexual choices, and the wisdom of relying upon the state to regulate sexual markets. They accordingly take opposing positions on issues that implicate both, such as the regulation of pornography and the legalization or criminalization of sex work. They hold contrasting views regarding the value of the insularity of private and intimate spheres: liberals and liberal feminists hold the quintessentially liberal commitment to the private sphere as a realm of free individual choice, individuation and maturation, while radical feminists, echoing general themes in radical legal scholarship, contest the distinction between the public and private and even more sharply contest the freedom of choices made within the private sphere, focusing on the coercive impact of individuals or institutions who retain relative power over others in those spaces. 
Their oppositional nature, however, should not be overstated. In some contexts their approaches are complementary. Thus, while liberal feminists target state and employerbased discrimination and look to nondiscrimination principles and formal equality as a key to women's inclusion and empowerment, radical feminists target the private alienation and appropriation of women's sexuality by men and the resulting subordination of women and look to legal tools, including civil rights laws, reform of criminal law and anti-pornography regulations, to end that subordination. On some of these issues - the regulation of pornography and decriminalization of sex work - liberal and radical feminist approaches directly conflict. On other issues, there is less conflict and quite a bit of shared ground and mutual support. Although sometimes for different reasons or with different emphases, both liberal and radical feminists concur on the need to end overt and covert discrimination against women at work, to increase women's role in political life, to provide equal educational opportunities on college campuses and to assure women's reproductive autonomy, in part by legally guaranteeing safe and legal access to both birth control and abortion.

The deep theoretical differences between radical and liberal legal feminism, however, are sharp, and it is those differences that dominated intra-feminist dialogue and debate during the 1970s and 1980s, most famously over MacKinnon and Dworkin's proposed anti-pornography regulations. ${ }^{34}$ By 1990 , however, the sex wars had begun to abate, and, at the same time, liberal and radical feminism began to lose their joint monopolistic hold on feminist scholarship. This eventually opened space for the development of a plurality of theoretical approaches, as well as a pragmatic openness to hold starting premises tentatively rather than dogmatically, a pragmatism that has held into the present. The results in feminist theory generally are a less fervent commitment to the theoretical premises of either liberal or radical feminism and more interest in the development of doctrine in ways that would demonstrably help women's lives, untethered to overarching grand narratives. The loosening of the hold of these structuralist approaches created room for the entry of alternative theoretical approaches, which in turn suggested additional doctrinal reforms. Several such alternatives are explored in the chapters that follow and are briefly mentioned here.

\section{A. Relational Feminism}

One such alternative was the emergence of what came to be called relational feminist legal theory. One core and perhaps organizing insight of relational feminists was that women's subordination, or inequality, might be traced at least in part not to their sexuality, as per radical feminism, or to their differential treatment by the state, as per liberal feminism, but rather to their maternalism and, more broadly, to their disproportionate role in caregiving and reproductive labor in and outside of families. Put in terms congenial to radicalism, the key insight was that men clearly have an interest in the appropriation and exploitation of women's maternal labor no less than in the appropriation and exploitation of their sexual labor, and therefore much the same dynamic explored by radical feminists in the context of sex may well be true in the often all-consuming context of maternity. The felt male entitlement to women's bodies, to

34 See chapter by Nan D. Hunter, Feminism, sexuality and the law, in this volume. 
their reproductive labor and to their borne children, the control by men of women's pregnancies and impregnability and the defining of women's nature in a way that facilitates this exploitation are all central insights of relational feminism. In the maternal context no less than in the sexual, law contributes to the appropriation and exploitation of women's labor both directly and indirectly - directly through prohibitions on women's participation in most male careers, trades and workplaces and restrictions on the franchise, and indirectly, but just as profoundly, through the lack of substantial assistance with child care, restrictions on rights to abortion and regulation and preservation of traditional roles in family life. In terms congenial to liberalism, the failure of the state to compensate women for their maternal labor or to recognize women's right to control it themselves constitutes a massive failure of the liberal state, comparable to the state's complicity in slavery.

More broadly, relational feminists have pointed to a plethora of ways in which law has failed to acknowledge the particular harms women sustain by virtue of their disproportionate involvement in relational life, from restrictions on tort recovery for emotional harms, ${ }^{35}$ to the lack of any legal mechanism for sharing the costs of unintentional pregnancies ${ }^{36}$ and to the absence of any way to compensate women for their disproportionate domestic labor in the home, either contract based or regulatory. ${ }^{37}$ At the same time, relational feminists sometimes argue, maternal labor, care for dependents in the home, the preservation of relationality in households and neighborhoods and even the uncompensated nature of that labor arguably instill in the women who disproportionately perform it a way of being in the world and of viewing oneself and others that skews toward an ethic of care, rather than an ethic of principle, and a sensitivity to the risks and dangers of excessive commodification - particularly of labor - in the commercial and public worlds. An ethic of care, as well as a skeptical stance toward the commodification of labor, are neither rewarded nor reflected in either liberal legalism or radical legalism, although they have close ties to the communitarianism arguably at the heart of the latter. ${ }^{38}$ Women's individual economic well-being may take a hit by their embrace of an ethic of care, particularly where that ethic is informed in part by willing self-sacrifice which is itself tainted by false consciousness. The world, though, may take a hit by virtue of the lack of such an ethic of care in public life, both in liberal and non-liberal states. One impulse within relational feminism is to highlight this paradox and to find a way to resolve it that heals the world as well as protects women against abuse and exploitation.

\section{B. Vulnerability Theory}

A closely aligned approach pioneered by Martha Albertson Fineman has focused feminists and feminist theorists on the under-appreciated and under-theorized role of vulnerability and dependency in virtually all of our individual lives and the communities we form, as well as the well-being and rights of those who care for

35 See Chamallas, supra note 12.

36 See Shari Motro, Preglimony, 63 StAn. L. Rev. 647 (2011).

37 See Keren, supra note 19.

38 See chapter by Robin West, Relational feminism and law, in this volume. 
dependents. As she recapitulates in her chapter in this volume, Fineman argued in a body of scholarship developed over several decades that liberalism and liberal legalism have long presupposed independent, autonomous, mature individuals as the primary subjects of the liberal state and of liberalism generally. ${ }^{39}$ Constitutional law presupposes fully formed, rational, independent and mature beings as its freely thinking, acting and associating subjects; contract and property law presuppose independent contractors and owners who can and should achieve self-sufficiency; criminal law presupposes victims who are independent of those who may prey on them and defendants who can be incarcerated with no significant costs to anyone but themselves. All of this, Fineman has argued, belies human and social reality. For much of our lives we are dependent on others, and for much of our lives (for many of us, disproportionately women, for most of our lives), we are caregivers for those who are dependent upon us. When we care for dependents, we ourselves become vulnerable: the unpaid caregiver, bound by ties of affection, obligation or duty, is to some degree incapacitated from wage labor, and the paid caregiver is rarely paid sufficiently to become fully autonomous. Yet the concerns, rights and vulnerabilities of those who care for dependents, whether those dependents be young children, aging parents or severely disabled relatives, are afterthoughts at most to liberalism. A liberalism reconfigured to center rather than marginalize the straightforward biological fact of dependency, rather than independence, and caregiving, rather than self-serving labor, would be demonstrably better for caregivers generally, the majority of whom are still women, and for the dependents who rely upon them.

\section{Intersectional Feminism(s)}

Feminist scholars of color have critiqued and then enriched feminist legal theory across the board, first by highlighting the degree to which feminism in all the forms rehearsed above has prioritized the perspectives and interests of white women, and then by bringing the intersectional perspectives of black, brown, lesbian and disabled women to bear on problems of subordination and discrimination. ${ }^{40}$ The experiential base of liberal, relational and radical feminism, according to early critical race theorists, neglected or marginalized the experiences of women of color, and the resulting conceptions of law and life show it. Black women, for example, have a different history of engagement and disengagement with the state's family law than do white women, a different history of engagement in the paid labor force, a different history of victimization from domestic violence, a different history of solidarity with black men falsely accused of rape by white women and white communities, a different history of engagement and disengagement with the state's laws of marriage and motherhood and

39 See chapter by Martha Albertson Fineman, The limits of equality: vulnerability and inevitable inequality, in this volume.

40 See chapters by Wing, supra note 8; chapter by Dorothy E. Roberts, Critical race feminism, in this volume; Kimberlé Crenshaw, Demarginalizing the Intersection of Race and Sex: A Black Feminist Critique of Antidiscrimination Doctrine, Feminist Theory and Antiracist Politics, U. ChI. Legal F. 139 (1989); Angela P. Harris, Race and Essentialism in Feminist Legal Theory, 42 STAN. L. REV. 581 (1990). 
vastly different experiences with discrimination at work and in educational institutions. ${ }^{41}$ Asian American women and Latinas have different experiences with immigration law, different challenges with language and accent discrimination and different experiences with barriers to employment. ${ }^{42}$ Lesbian and disabled women have different experiences of law than do straight or non-disabled women. ${ }^{43}$ The collective message of these comparative analyses is that the claims of liberal feminism that the major impediment to women's advancement is discrimination by the state and major employers, or of radical feminism that sexuality is the key to women's subordination, or of relational feminism that maternalism is central to women's lesser lives are all grounded in the experiences of white women, with their distinctive array of privileges and challenges. Feminist legal theories, accordingly, have not incorporated the perspectives of women who experience multiple forms or sources of discrimination or subordination or different forms of community and family than those of white women.

While this critique is key, it has been the affirmative presentation of distinctively intersectional experiences of women of color that has fundamentally reshaped feminism. Indeed, the intersectional experiences of women of color, as well as those of lesbian, disabled, trans or queer women, have become not just central to but in some ways emblematic of the development of contemporary feminist legal theory. They collectively evidence a conscious attempt to direct feminism - and by implication and extension, all legal reform movements - toward a centering of the experiences of persons previously marginalized or sidelined, or most subordinated, and to re-imagine those experiences and their subjects as foundational rather than peripheral to the development of a sound critical as well as normative jurisprudence. The result for feminism and for feminist legal theory has not only been to aspire to an inclusive and intersectional self-understanding but also to embrace pluralism rather than essentialism regarding women's nature, nimbleness rather than rigidity with respect to method and strategy, and pragmatism rather than ideology with respect to goals and aspirations. The movements toward intersectionality counsel broadly for the need to attend to the voices at the bottom of various ladders of hierarchy and success, rather than solely to the voices of those seeking to crack glass ceilings. Thus, intersectional feminist legal theory has ushered in not only greater respect and attentiveness to marginalized voices but, just as important, a form of theory that is attentive to context, to particularity and to immediacy, eschewing grand theories of women's nature or universal human nature as well as broad claims of shared values, such as liberty or even equality. On the basis of this contingency, pragmatism, fluidity and plasticity, feminist legal scholars might then fashion doctrinal arguments that respond to the needs of all women, as well as of all those who depend on or befriend them, and build the coalitions necessary to address those needs.

41 Crenshaw, supra note 40, at 140.

42 Mari J. Matsuda, Looking to the Bottom: Critical Legal Studies and Preparations, 22 HaRv. Civ. RTS.-Civ .LiBS. L. Rev. 323, 356 (1987).

43 See, e.g., Patricia Cain, Lesbian Perspective, Lesbian Experience, and the Risk of Essentialism, 2 VA. J. SOC. POL'Y \& L. 43 (1994). 


\section{Postmodern, Queer, Sex-Radical and Sex-Positive Feminism(s)}

In the last decade, a distinctively queer legal theory has emerged from an engagement of feminists in law with the representations of sexual and gender fluidity, the politics and aspirations of sex-positivist and sex-liberatory feminism and postmodern skepticism toward claims of generality and truth. Queer theorists, both feminists and otherwise, have expressed doubts about the broad descriptive claims of both radical and relational feminism regarding the root of female subordination, as well as reservations regarding the normative or aspirational goals reflected in feminist attempts to arrest the appropriation of women's sexuality, particularly those strategies that rely upon criminal law or harassment law. ${ }^{44}$ 'Carceral feminism' has been labeled and then targeted by queer feminists as an umbrella term encompassing feminist movements - such as anti-rape and anti-sexual assault campaigns - that unduly rely upon the state, and particularly the criminal justice system, to police against and then punish and deter sexual and relational violence. ${ }^{45}$ Claims of injury, and particularly claims of sexual assault, according to one influential strand of queer theory, might sometimes reflect a real injury but might sometimes reflect nothing more than internalized sexual self-loathing and shame regarding the purported victim's own sexual impulses - what came to be called in the 1990s a sex panic, meaning a cultural moment that transformed openly expressed sexuality into a moral and then a legal crisis. ${ }^{46}$ Thus, queer theorists who so hold have sought to decentralize the accounts of women claiming injury from sexual harassment on the job or from rape or assault in the home or on the street and to attend instead to the accounts of women and men who resist the repression of sexual expression in all forms, whether in the name of traditional conceptions of sexual morality or feminist conceptions of sexual harms. ${ }^{47}$ These claims have given new life and new form to the sex wars from two decades back, with the liberal and libertarian premises of the anti-censorship side of those debates recharacterized and broadened so as to be grounded in these queer and loosely postmodern or poststructuralist premises. ${ }^{48}$ As has been true of intersectional feminists, however, beyond these particularized disagreements, queer theorists have more broadly called on feminism and feminist theorists to embrace a theoretical pluralism and to eschew reliance on grand narratives of sexual harm and injury across the board, as well as on grand general claims about the nature or identity of women, men, girls or boys.

\footnotetext{
44 Janet E. Halley, Sexuality Harassment, in DiRECTIONS In SEXUAl HaRASSMENT LaW 182 (Catharine A. MacKinnon and Reva Siegel eds., 2004); Jeannie Suk, Criminal Law Comes Home, 116 YALE L.J. 2 (2006).

45 For a general discussion and response to this criticism in the international context, see Menon, supra note 11; for discussion in the US domestic context, see Nourse, supra note 5.

46 See Halley, supra note 44.

47 Janet Halley, The Politics of Injury: A Review of Robin West's Caring for Justice, 1 UNBOUND 65 (2005).

48 See Hunter, supra note 34.
} 


\section{E. Socialist Feminism}

Finally, some feminist legal scholars over the last few years, including prominently Cynthia Grant Bowman, both an editor of and contributor to this volume, have re-enlivened the project of socialist feminism, spelling out its implications for both law and legal reform. ${ }^{49}$ The focus of the newly emergent, or re-emergent, socialist feminist legal theory is on the relation of women to the worlds of production and reproduction, with an eye toward the role of law in appropriating their surplus labor value in both realms. Such an analysis promises a fresh look at the nature of women's subordination that avoids privileging either the appropriation of sexuality or the exploitation of their maternal labor but seeks to account for both, as well as for the undervaluation of women's labor in the paid labor markets. Socialist feminist legal theory thus constitutes a challenge to virtually all of the theoretical approaches that have preceded it. It departs from liberal feminism's grand commitments to liberal values, from the defining radical feminist claim that sexuality is the linchpin of subordination, the relational feminist understanding that maternalism is the sole or primary locale of such exploitation, and intersectional, postmodern and queer claims that feminism has nothing further to learn or absorb from overarching narratives or definitional accounts.

\section{CONCLUSION}

The debates between and among liberal, radical, relational, socialist, postmodern, queer, sex-positive and intersectional feminists are ongoing, and there is by no means a clear trajectory from which we might predict where all this is heading. The debates as well as the particular positions continue to be influenced by both political shifts in the world and intellectual movements in the legal academy. The \#MeToo movement has brought sexual harassment and sexual harassment law into clearer focus and made more compelling (and for a new generation) radical feminist claims that the sufferance of those assaults is a near universal and hence defining condition of women's lives. Liberal feminism continues to play the central role in the ongoing efforts of feminist litigators and advocates to preserve a domain of reproductive freedom and reproductive rights for women facing unwanted pregnancies. Relational feminism and vulnerabilitybased feminist approaches continue to serve as a grounding for broad claims of women's and men's needs for greater assistance in providing for the needs of dependents. Queer and intersectional feminisms continue to provoke and challenge, often resting on the perspectives of once marginalized outsiders, including women of color, lesbians, trans-women, trans-men and children. In short, all of these movements continue to be influenced by legal developments as well as by non-feminist theoretical movements. And all continue to lay claim to descriptive and analytic accounts of women's continuing inequality, as well as normative or aspirational claims regarding the use of law and legal reform to combat it. While aspirations for pragmatism, pluralism and theoretical fluidity are fair descriptors of the current state of feminist

49 See chapter by Cynthia Grant Bowman, Socialist feminist legal theory: a plea, in this volume. 
legal theory, that very fluidity - and the pragmatism it counsels - could themselves eventually be subjected to critique and change. It is fair to predict that the aspirations of theoretically grounded feminisms for causal accounts of women's subordination and for narratives that explain legal choices and strategies that might combat it will persist, at least as long as that subordination itself persists as a widespread and diminishing force in women's and girls' lives. 